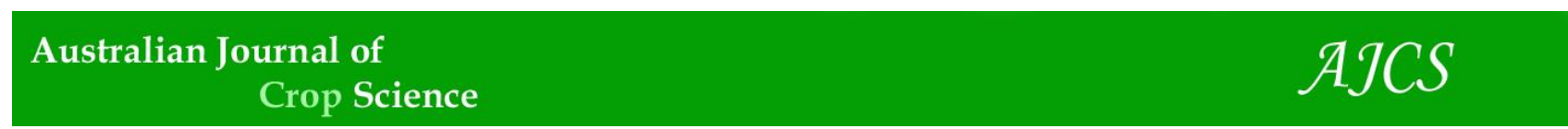

AJCS 12(05):794-799 (2018)

ISSN:1835-2707

doi: $10.21475 /$ ajcs.18.12.05.PNE979

\title{
Trichoderma harzianum and some antioxidants for suppressing faba bean chocolate spot incidence under natural field infection
}

\author{
Nehal Samy El-Mougy, Mokhtar Mohamed Abdel-Kader* \\ Plant Pathology Department, National research Centre, Dokki, Giza 12622, Egypt \\ *Corresponding author: mokh_nrc@yahoo.com
}

\begin{abstract}
Chocolate spot is one of the most important diseases affecting faba bean in Egypt. The field experiment was conducted for two cropping seasons with the objective of evaluating the efficacy of Trichoderma harzianum and five antioxidant agents, i.e. Vitamin C, Vitamin E, Selenium, VitaMax Plus against Chocolate spot disease incidence and severity under field conditions. Field study was performed during two successive growing seasons (2015/2016 and 2016/2017) using the bioagent T. harzianum and antioxidants individually or in combinations. All treatments were applied as faba bean foliar spray three times with 15 days interval starting at the beginning of flowering stage. Percentages of disease incidence and severity were measured for each growing season and their mean was calculated. Results showed that all applied treatments could reduce chocolate spot disease incidence at a range of 66.6 to $92.2 \%$ compared to the fungicide Diathane M45 (39.0\%). Meanwhile, disease severity followed similar trend. It was reduced by a range of 38.7 up to $75.1 \%$ and $20.9 \%$ relatively to control at applied treatments of antioxidants individually or combined with $T$. harzianum and the fungicide, respectively. Combined treatments showed that when $T$. harzianum combined with either one or all of the used antioxidants, they had superior effect for reducing disease incidence and severity on faba bean plants compared to fungicide and the control. Meanwhile, all of the antioxidants in combination showed lesser suppression effect on disease incidence and severity than individual treatment. The present findings demonstrate that bio-agent $T$. harzianum integrated with antioxidant as foliar spray treatment can be recommended for the future use in a commercial scale for effective management of Chocolate spot on faba bean.
\end{abstract}

Keywords: Antioxidants, chocolate spot, disease control, faba bean, T. harzianum.

Introduction

Faba bean (Vicia faba L.) is one of the earliest domesticated food legumes in the world, and it is cultivated mainly as human food in developing countries and as animal feed in industrialized countries (Teshome and Tagegn, 2013). The chocolate spot disease caused by Botrytis fabae Sard. and $B$. cinerea Pers. is one of the most economically important diseases that damage the foliage, limit photosynthesis activity, and reduce the faba bean production (Torres et al., 2004). The disease incidence is favored by warm humid conditions that extend for $4-5$ days and can spread rapidly within the crop. It typically develops later in the season during flowering and after canopy closure. Yield loss due to chocolate spot results from pod abortion and plant damage (Hawthorrne et al., 2012). Major yield reduction usually resulted from infection of flower, leaves and stems as along elliptical of reddish to chocolate brown color spots, with darker margins that are fairly defined and often a concentric circular pattern (El-Metwally et al., 2010; Hailu et al., 2014). In Egypt, this disease causes serious damage to the faba bean plant and decrease of the yield production more than 50\% (El-Sayed et al., 2011; El-Banoby et al., 2013; El-Kholy, 2014) especially in the north and middle parts of the
Egyptian Delta region. Several strategies can be employed for the management of chocolate spot disease in faba bean crop. Application of fungicides has been the most effective and widely used strategy and provides effective and reliable disease control measure. However, their use is expensive and may also result in reduction in populations of beneficial microorganisms. This problem has been further complicated by the development of fungicidal resistance, in addition to its negative effects on public health and environmental balance (Khaled et al., 1995). Therefore, the use of biological control agents as fungicide alternatives for disease management has become more attractive. In this regard the aim of this work is to evaluate the effect of some antioxidants individually or combined with bioagent $T$. harzianum as foliar spray against faba bean chocolate spot incidence and severity under field conditions.

\section{Results}

The causal organism(s) of faba bean chocolate spot

The fungal isolation was performed from naturally infected leaves, stem and pods of faba bean ( $c v$. Giza 3 ) during the 
growing season 2014/2015. According to morphological and cultural characterization the identified fungi were Botrytis fabae Sard. and B. cinerea Pers. (Gilman, 1957; Barnet and Hunter, 1972). The frequency of isolated fungi revealed that the number of Botrytis fabae Sard. isolates showed more occurrence recorded as $76.8 \%$ compared $22.7 \%$ for $B$. cinerea Pers. These results are in a harmony with those recorded by other investigators (El-Kholy, 2007 and Mahmoud et al., 2012).

\section{Disease assessments under field conditions}

Field studies were performed during two successive cultivated seasons (2015-2016 and 2016-2017) to evaluate the efficacy of spraying faba bean plants with some antioxidants and bioagent on chocolate spot disease incidence and severity. Data presented in Table (1) showed that all applied treatments revealed high response against disease incidence and severity compared to untreated control. Foliar spray with $T$. harzianum revealed the lowest disease incidence $(1.7 \%)$ followed by $(3.3 \%)$ at combined treatments of $T$. harzianum and the antioxidants, Vitamin $\mathrm{E}$, Vitamin C, Enervit, Selenium or VitaMax Plus. Meanwhile, disease incidence at foliar spray with individual treatment with Selenium or VitaMax Plus revealed $8.3 \%$ followed by $10.0 \%$ at Vitamin E, Vitamin C and Enervit treatments. Chocolate spot incidence recorded as $6.7 \%$ at combined treatments of all applied antioxidants together individually or with T. harzianum. Data presented in (Table 1) also showed a similar trend concerning disease severity. The severity of injury showed the aggressiveness of the causal pathogen of chocolate spot disease that it expressed in higher figures ranged from $10.27 \%-32.73 \%$ compared to lesser records of disease incidence which ranged from 1.7 $18.3 \%$ using the same applied treatments. Meanwhile, the control untreated faba bean plants disease incidence and severity recorded 30.0 and $41.38 \%$, respectively (Table 1 ). On the other hand, reduction in disease incidence and severity were illustrated in figure (1). Reduction in disease incidence recorded as 94.3, 92.5 and $92.5 \%$ at applied treatments of only $T$. harzianum and all antioxidants together with or without $T$. harzianum, respectively. Moreover, disease reduction by $89.0 \%$ was recorded after treatments using $T$. harzianum combined with vitamin $\mathrm{E}$, vitamin C, Enrevit, selenium and VitaMax Plus. Meanwhile individual treatment of vitamin $E$, vitamin $C$, Enrevit recorded $66.6 \%$ and selenium, VitaMax plus caused $72.3 \%$ minimization in disease incidence. Foliar spray with $T$. harzianum could minimize disease severity by $75.1 \%$ in relative to control treatment followed by combination of $T$. harzianum with applied antioxidants, vitamin E, vitamin $\mathrm{C}$, selenium, Enrevit and VitaMax Plus treatments which their calculated reduction was found to be $70.2,67.7,65.4,62.7$ and $60.5 \%$, respectively. Also, reduction in disease severity by 58.0 and $57.2 \%$ was observed in treatments of all antioxidants combined together with or without $T$. harzianum. Applied treatments with individual antioxidant of Enrevit, vitamin E, vitamin C, VitaMax Plus and selenium reduced disease severity in ascending order by $38.7,40.1$, $43.6,46.0$ and $48.5 \%$, respectively. Application of the fungicide Diathane M45 revealed the lowest reduction in disease severity calculated as $39.0 \%$ compared to control.
The presented data showed a synergistic effect between the antioxidants used against the disease incidence and severity. The obtained results in the present study revealed that faba bean chocolate spot ranged between 1.7 to $18.3 \%$ and 10.27 to $32.37 \%$ at all applied treatments with reduction of 20.9 to $75.1 \%$ and 39.0 to $94.3 \%$ for disease incidence and severity, respectively.

\section{Discussion}

Several workers reported limitation in faba bean production due to Leaf diseases. The most leaf diseases affect faba bean crop are caused by the fungi Alternaria sp., Botrytis cinerea, B. fabae, Mycosphaerella sp., Oidium sp. and Uromyces viciae-fabae (Otazu et al., 1982). Chocolate spot disease was reported to cause destructive loss in plant production in many countries that, for example, recorded in Bolivia between 20 and $80 \%$ (De Quiton, 2000).

A successful disease-control program could involve just a single practice, but the long term reduction of disease losses generally requires the application of several control measures. The best way to ensure success of a diseasemanagement program is to use integrated disease-control measures (Dik et al., 2002). Generally, IPM is regarded as the use of environmentally safe practices to reduce the disease incidence and development or the use of multiple control tactics integrated into a single pest control strategy (Zinkenagel et al., 2002). For example, different natural products such as biocontrol agents, plant extracts, essential oils, antioxidant, growth regulators and natural compounds were used as an IPM program which takes slightly different approach in plant disease control (Bindu and Kumar, 2009; Sharma et al., 2012). Furthermore, some fungal and bacterial strains enhance plant growth and are currently being used as potential antagonist for controlling multiple fungal plant pathogens (Bendahmane et. al., 2012). A number of authors indicate that the effect of leaf pathogens can be reduced by biological control with Trichoderma (Elad, 2000; Williamson et al., 2007). In general, biological control using microbial antagonists has shown potential as an alternative for natural control of plant pathogens instead of synthetic chemical fungicides (Droby et al., 1989). In order to completely eliminate the use of synthetic fungicides, more environmentally friendly and harmless compound (s) should be explored to improve the activity of the antagonist. Certainly, the suppression of plant pathogens can be achieved by a range of control methods that differ in their effectiveness, duration and cost (Shtienberg, 2000). Therefore, the present study conducted using the foliar spray containing the bioagent $T$. harzianum together with several antioxidants as fungicide alternatives for controlling chocolate spot disease incidence and severity under natural field infection. Similarly, Coca-Morante and Mamani- Alvarez (2012) studied the effect of five isolates of $T$. harzianum and three fungicides individually or in combination as seed or foliar treatments against faba bean leaf spot disease incidence. They found that seed combined with foliar treatments were more effective for controlling disease than leaf treatments on their own. They added that compared to chemical treatments, biocontrol with Trichoderma spp. preliminary was found to provide good control of the disease. They conclude that spraying with Trichoderma spp. 
Table 1. Influence of foliar spray with $T$. harzianum and some antioxidants against chocolate spot disease incidence and severity on faba bean under field conditions.

\begin{tabular}{lcc}
\hline Foliar treatment & \multicolumn{2}{c}{ Chocolate spot $\%$} \\
\cline { 2 - 3 } Vitamin E & incidence & Severity \\
Vitamin C & $10.0 \mathrm{c}$ & $24.77 \mathrm{c}$ \\
Enervit & $10.0 \mathrm{c}$ & $23.32 \mathrm{~cd}$ \\
Selenium & $10.0 \mathrm{c}$ & $25.33 \mathrm{c}$ \\
VitaMax plus & $8.3 \mathrm{~d}$ & $21.23 \mathrm{~cd}$ \\
T. harzianum & $8.3 \mathrm{~d}$ & $22.33 \mathrm{~cd}$ \\
T. harzianum + Vitamin E & $1.7 \mathrm{~g}$ & $10.27 \mathrm{e}$ \\
T. harzianum + Vitamin C & $3.3 \mathrm{f}$ & $12.33 \mathrm{e}$ \\
T. harzianum + Enervit & $3.3 \mathrm{f}$ & $13.34 \mathrm{e}$ \\
T. harzianum + Selenium & $3.3 \mathrm{f}$ & $15.43 \mathrm{e}$ \\
T. harzianum + VitaMax plus & $3.3 \mathrm{f}$ & $14.31 \mathrm{e}$ \\
Vitamin E + Vitamin C + Enervit + Selenium + VitaMax plus & $3.3 \mathrm{f}$ & $16.33 \mathrm{~cd}$ \\
T. harzianum + Vitamin E + Vitamin C + Enervit + Selenium + VitaMax plus & $6.7 \mathrm{e}$ & $17.37 \mathrm{~d}$ \\
Dithane M45 (2.5 g/L) & $6.7 \mathrm{e}$ & $17.67 \mathrm{~d}$ \\
Control & $18.3 \mathrm{~b}$ & $32.73 \mathrm{~b}$
\end{tabular}

Mean values within each column followed by the same letter are not significantly different at $P \leq 0.05$.

* Percentage of faba bean disease incidence and severity calculated as average disease incidence at the two growing seasons

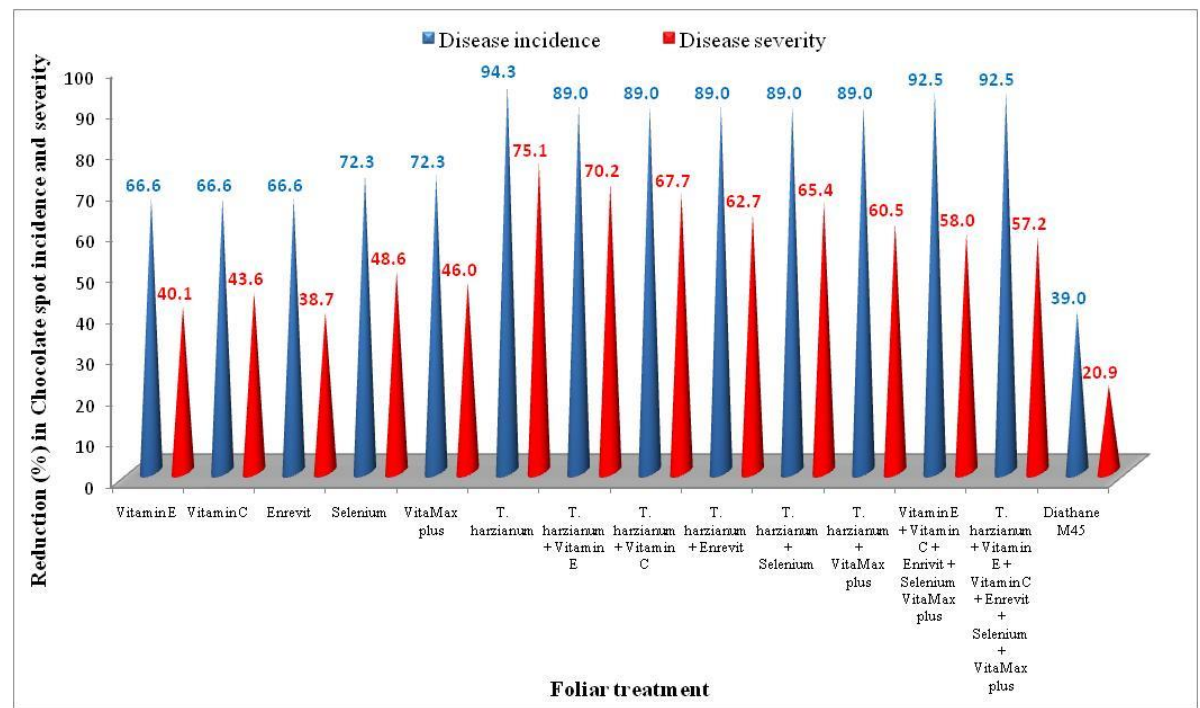

Fig 1. Reduction (\%) in chocolate spot disease incidence and severity of faba bean in response to foliar spray with $T$. harzianum and some antioxidants under field conditions.

appears to reduce the impact of leaf spot pathogens on faba bean. The genus Trichoderma is the most promising and effective biocontrol agent. Trichoderma as antagonist controlling wide range of microbes and their mechanism of mycoparasitism is much more complex, involves nutrient competition, hyperparasitism, antibiosis, space and cell wall degrading enzymes (Chet et al., 1997). Also, Abdel-Kader et al. (2012) evaluate the efficacy of bioagents, Trichoderma harzianum, T. Viride, Bacillus subtilis, Pseudomonas fluorescens and Saccharomyces cerevisiae as foliar spray against vegetables foliar diseases, i.e. powdery, downy mildews of cucumber, cantaloupe and pepper as well as early, late blights of Tomato under open greenhouse conditions. They found that application with either $T$. harzianum or $B$. subtilis showed significant reduction in diseases incidence compared the other applied bio-agents. Meanwhile, the other bio-agent treatments recorded moderate reduction in this concern. Moreover, a field experiment of Deore and Sawant (2001) who investigate the efficacy of the culture filtrates of $T$. viride, $T$. harzianum, $T$. hamatum, T. longiflorum and T. koningii and the fungicide carbendazim against the powdery mildew (Leveillula taurica) of guar. They found that all treatments recorded beneficial effects on growth parameters and disease control. Also, another work done by Elad (2000) has shown that Trichoderma harzianum which is regarded as a model for demonstrating biocontrol under commercial conditions and deciphering the mechanisms involved. He added that this bio-agent controls the foliar pathogens, Botrytis cinerea (gray mold), Pseudoperonospora cubensis (downy mildew), Sclerotinia sclerotiorum (foliar blight) and Sphaerotheca fusca (powdery mildew) in cucumber under commercial greenhouse conditions. Similarly, Perello et al. (2003) reported that Trichoderma spp. significantly reduce leaf spot in wheat caused by Pyrenophora tritici-repentis (anamorph = Drechslera tritici-repentis), both in vitro and under the greenhouse conditions. 
The present study has demonstrated that all treatments tested using antioxidants have antifungal potential activities and could be useful both individually and when combined with the bioagent $T$. harzianum against chocolate spot disease incidence and severity. Antioxidants represent a special important class of preservatives as, unlike bacterial or fungal spoilage (Iverson, 1995). The efficacy of antioxidant used in present study could be attributed to its chemical constants of Vitamins used. It was reported that antioxidants are vital to raise host plant resistance, trigger innate immunity in plants to refine and promote methods of defense to the plant against the pathogens (Madukwe et al., 2013). When the antioxidants used in our endeavor, we kept in mind the fact that, there is no much research yet in this area. The newest research is confirming the hypothesis that vitamins serve healing purposes for the plants that produce them. Our knowledge about these antioxidants as follows: Vitamin C (ascorbic acid), Vitamin E is the collective name for a set of eight related tocopherols and tocotrienols, which are fat-soluble vitamins with antioxidant properties (Herrera and Barbas, 2001). The ingredients of Enrevit are, Fructose syrup (42.6\%) - Glucose syrup (16.5\%) -Isomaltulose (16.2\%) - Gelling agent: pectins -Acidifier: citric acid - Colouring: caramel - Acidity regulator: sodium citrate - Caffeine (0.11\%) -Preservatives: sodium benzoate, potassium sorbate -Stabilising agents: tetrasodium diphosphate, sodium polyphosphate, calcium monophosphate. Selenium functions through selenoproteins, several of which are oxidant defense enzymes. The selenium in several selenoproteins has a biochemical role in oxidant defense, thus maintaining normal physiological function, and as such plays a role as a dietary antioxidant. The commercial drug of VitaMax Plus is dietary supplement with antioxidants contains in major multi-vitamin $B\left(B_{1}, B_{2}, B_{6}\right.$ and $\left.B_{12}\right)$ as well as some minerals and amino acids. Our investigation with vitamins $C$ and $E$ is beginning to show promise. Some plants have shown increased growth and ability to fight off bacterial disease with Vitamin C added to the soil or water (Last et al., 1997; Burkey, 2003; Smirnoff et al., 2007; Li et al., 2009). The antioxidants "vitamins $C$ and $E$ play an important role in protecting cells and neutralizing free radicals during infection in addition to crucial roles in defense (De Pinto and De Gara, 2004; Sharma et al., 2012). In other reports, Vitamin C, vitamin E and selenium have frequently been called dietary antioxidants since in some cases they counteract oxidative damage to biomolecules (Halliwell, 1999), and the possibility exists that increased intakes of these compounds may protect against chronic disease.

\section{Materials and Methods}

\section{Experimental materials}

Faba bean (Vicia faba L.) seeds cv. Giza 3 obtained from Vegetables Crop Research Department, Agricultural Research Centre, Giza, Egypt. The antioxidants Vitamin C, E, Selenuim and other commercial antioxidants (Enervit and VitaMax Plus) were purchased from Al-Gamhoria Company Ltd. for chemicals and medicinal instruments, Cairo, Egypt. The used antioxidants contain one or more active ingredients. Therefore their tested concentration (2\%) based on each antioxidant weight in powder phase ( 2 grams) to the volume of $100 \mathrm{~mL}$ water.

Meanwhile, the bioagent used in this study is a candidate antagonistic isolate of Trichoderma harzianum obtained from the culture collection Unit, Plant Pathology Dept., NRC, Egypt. The collected spores of seven days old from $T$. harzianum growing culture were prepared as spore suspension and adjusted to the concentration of $10^{8}$ per 1 $\mathrm{mL}$ water with the aid of haemocetometer slide.

\section{Isolation and Identification of the causal organism(s)}

During 2014/2015 growing season, faba bean samples (leaves, stem and pods) showing chocolate spot disease symptoms were collected from the experimental field and transferred to the laboratory for isolating trail. Samples were thoroughly washed with tap water and dried between two sterilized filter papers, then cut into small pieces $(0.5 \mathrm{~cm})$ and surface sterilized by dipping in $1 \%$ sodium hypochlorite solution for $2 \mathrm{~min}$. Afterwards, samples were washed for three times with sterilized distilled water, placed onto filter paper to air dry. Five pieces were plated into Petri dishes $(9 \mathrm{~cm})$ containing PDA medium supplemented with streptomycin sulphate at $100 \mathrm{ppm}$. The plates were incubated at $25 \pm 2^{\circ} \mathrm{C}$ for 7 days. The purification of the isolated fungi was performed by using hyphal tip method and the frequency percentage of each isolate was calculated. The purified isolates were subjected to microscopic examination and the isolated fungi were identified according to Gilman (1957) and Barnet and Hunter (1972).

\section{Experimental Materials and treatments:}

The field experiments were conducted for two successive growing seasons (2015/2016 and 2016/2017) at the Researches and Production Station, National Research centre, Nobaria region, Beheira governorate, Egypt. This experiment was carried out to evaluate the efficacy of the bioagent Trichoderma harzianum and some antioxidants individually or in combinations as foliar spray treatments for controlling chocolate spot disease incidence and severity of faba bean. The fungicide Dithane M45 was applied as a comparison treatment.

The applied treatments were designed as following:

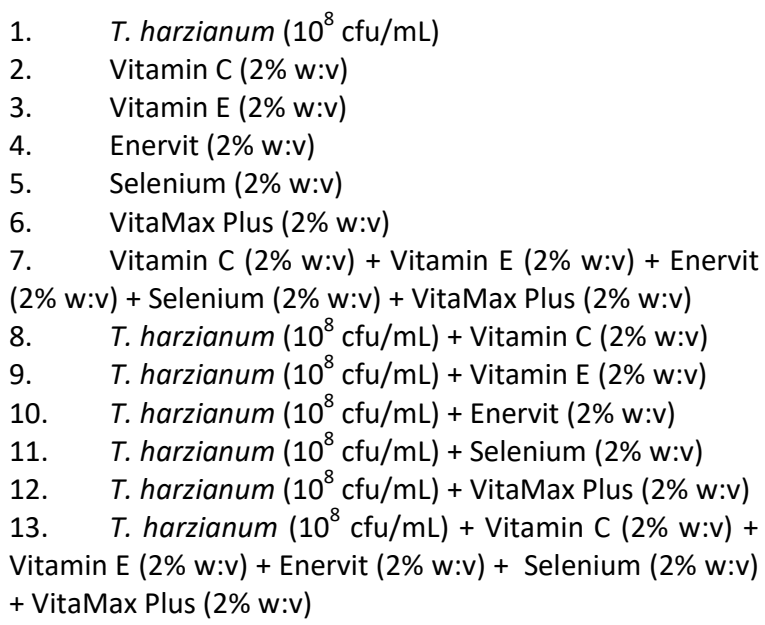


14. The fungicide Dithane M45 (2.5 g/L)

15. Untreated control (water)

\section{Experimental design and field plots}

The field experiment consisted of 75 plots, $7 \mathrm{~m} \times 6 \mathrm{~m}\left(42 \mathrm{~m}^{2}\right)$ each. Every individual plot was comprised of 12 rows where 30 holes existed per row. Five plots used as replicates for each particular treatment and five plots were also kept untreated as control. Faba bean seeds Giza, $3 \mathrm{cv}$. were sown in all plots at the rate of 3seeds/hole. All plots assigned for treatment in a completely randomized manner. All plots received the traditional agricultural practices, irrigation, fertilization, etc.

Certain weights of used antioxidants were added to $20 \mathrm{~L}$ water to obtain the proposed concentration used for each treatment. Meanwhile, the inoculum of the bioagent $T$. harzianum was used as spore suspension at the rate of $10^{8}$ $\mathrm{cfu} / \mathrm{mL}$. All foliar spray treatments were applied three times with 15 days interval starting at the beginning of flowering stage.

The percentage of chocolate spot disease incidence and severity were recorded 15 days after third spray treatment. The average percentage of disease incidence or severity was calculated for the two seasons.

\section{Disease incidence and severity assessments}

The disease incidence was determined using the formula of (DI \%) $=$ (No of infected plants/ total No. of examined plants) $\mathrm{x} 100$.

As for disease severity (DS\%), 100 leaves were randomly selected from 25 plants of each replication and graded in 1-9 scale after Bemier et al. (1993), then calculated using the equation adopted by Hanounik (1986) as follows:

$$
\mathrm{DS} \%=\frac{\sum(\mathrm{NPC} \times \mathrm{CR})}{\mathrm{NIP} \times \mathrm{MSC}} \times 100
$$

Where:

NPC $=$ Number of plants in each grade rate

$\mathrm{CR}=$ Grade rate

NIP = Number of infected plants

$\mathrm{MSC}=$ Maximum grade rate.

\section{Statistical analysis}

Tukey test for multiple comparisons among means was utilized as described by Neler et al. (1985).

\section{Conclusion}

The present work emphasizes the importance of Trichoderma as a biological control agent and its application towards management of plant diseases. The present work also revealed a significant reduction in chocolate spot incidence and severity of faba bean under field trials using integrated treatment application of antioxidants with the bioagent $T$. harzianum. It may be concluded that such treatments are considered applicable, safe and costeffective method for controlling such foliar diseases. It could be hypothetically suggested that combined treatments between antioxidants with the bioagent as foliar spraying might be used practically for controlling such foliar diseases replacing fungicides treatments.

\section{Acknowledgments}

This research was supported in part by In-House project No. 11030133 entitled "Pesticide alternatives against soilborne pathogens affecting legumes cultivation in North Egypt".

\section{References}

Abdel-Kader MM, El-Mougy NS, Aly MDE, Lashin SM, AbdelKareem F (2012) Greenhouse biological approach for controlling foliar diseases of some vegetables. Adv Life Sci. 2(4): 98-103.

Barnett HL, Hunter BB (1972) Illustrated genera of imperfect fungi. 3rd edition, Burgess Publishing Co. 273 pp.

Bendahmane BS, Mahiout D, Benzohra IE, Benkada MY (2012) Antagonism of three Trichoderma species against Botrytis fabae and $B$. cinerea, the causal agents of chocolate spot of faba bean (Vicia faba L.) in Algeria. World Appl Sci. J. 17: 278-283.

Bindu S, Kumar P (2009) In vitro antifungal potency of some plant extracts against Fusarium oxysporum. Int J Green Pharm. 3:63-65.

Burkey K (2003) Vitamin C Protects Stressed-Out Plants. The United States Department of Agriculture website. USDA, http://www.ars.usda.gov/is/ar/archive/jan03/plant0103.h $\underline{\mathrm{tm}}$

Chet I, Inbar J, Hadar I (1997) Fungal antagonists and mycoparasites. In: The Mycota IV: Environmental and Microbial Relationships. Wicklow DT and Soderstorm B, eds. pp 165-184.

Coca-Morante M, Mamani-Alvarez F (2012) Control of leaf spot diseases on ecotypes of faba bean (Vicia faba L.) Produced in the Andean Region of Bolivia. Am J Plant Sci. 3: $1150-1158$.

De Pinto MC, De Gara L (2004) Changes in the ascorbate metabolism of apoplastic and symplastic spaces are associated with cell differentiation. J Exp Bot. 55: 25592569.

De Quiton M (2000) “Enfermedades de Haba," In: H. Waaijen- berg and M. Caro, Eds., Programa Nacional de Legu- minosas de Grano: Resultados de Investigaciones, 1991- 1998, Cochabamba, 2000, pp. 59-88.

Deore PB, Sawant DM (2001) Management of guar powdery mildew by Trichoderma spp. culture filtrates. J Maharashtra Agric Univ. 25 (3): 253-254.

Dik A, Wubben J, Elad Y, Kohi J, Shtienberg D (2002) Combination of control methods against powdery mildew diseases in glasshouse-grown vegetables and ornamentals. Bull. Oil B Srop. 25 (10): 5-8.

Droby S, Chalutz E, Wilson CL, Wisniewski M (1989) Characterization of the biocontrol activity of Debaryomyces hansenii in the control of Penicillium digitatum of grapefruit. Can J Microbiol. 35: 794-800.

Elad $Y$ (2000) "Biological control of foliar pathogens by means of Trichoderma Harzianum and potential modes of action," Crop Prot. 19 (8): 709-714. 
El-Banoby FE, Abd-AllA MA, Tolba IH, Morsy AA, El-Gamal NG, Khalil MSA (2013) Biological control of chocolate spot disease of faba bean using some bioagents under field conditions. J Appl Sci Res. 9(6): 4021-4029.

El-Kholy RMA (2007) Control of chocolate spot disease in faba bean. J Agric Sci Mansoura Univ. 32(3): 2319-2335.

El-Kholy RMA (2014) Chemical and biological control of chocolate spot disease in faba bean under field conditions. Middle East J Agric Res. 3(2): 368-377.

El-Metwally MA, Ghanem KhM, Abd El-Hai KM (2010) Improving the performance of faba bean and controlling of chocolate spot disease using bio-compounds. Plant Pathol J. 9(4): 169-178.

El-Sayed AS, El-Shennawy RZ, Ismail Al (2011) Fungicidal management of chocolate spot of faba bean and assessment of yield losses due to the disease. Ann Agric Sci. 56: 27-35.

Gilman JC (1957) A manual of soil fungi. lowa State College Press, Ames. 2ed Edition, pp.450.

Hailu E, Getaneh G, Sefera T, Tadesse N, Bitew B, Boydom A, Kassa D, Temesgen T (2014) Faba Bean Gall: A new threat for faba bean (Vicia faba) production in Ethiopia. Adv Crop Sci Tech. 2: 144.

Halliwell B (1999) Antioxidant defense mechanisms: from the beginning to the end (of the beginning). Free Radic Res. 31:261-272.

Hanounik SB (1986) Screening techniques for disease resistance in faba bean. International Center for Agricultural Research in the Dry Areas (ICARDA), Aleppo, Syria, pp: 59.

Hawthorne W, Kimber R, Davidson J, Paull J, Brand J, Richardson H (2012) Faba bean disease management strategy- Southern region. Southern pulse, Australia. www.puleseaus.com.au.

Herrera E, Barbas C (2001) Vitamin E: action, metabolism and perspectives. J Physiol Biochem. 57 (1): 43-56.

Iverson F (1995) Phenolic antioxidants: health protection branch studies on butylated hydroxyanisole. Cancer Lett. 93(1):49-54.

Khaled AA, Abd El-Moity SMH, Omar SAM (1995) Chemical control of some faba bean disease with fungicides. Egypt J Agric Res. 73: 45-56.

Last R, Conkin P, Thompson B, Williams E (1997) Environmental stress sensitivity of an ascorbic aciddeficient Arabidopsis mutant. Proc Nat Acad Sci. USA

Li S, Xue L, Xu S, Feng H, An L (2009) Mediators, genes and signaling in adventitious rooting. Bot Rev. 75:230-247.

Madukwe EU, Ezeugwu JO, Eme PE (2013) Nutrient composition and sensory evaluation of dry Moringa Oleifera aqueous extract. Int J Basic Appl Sci. 13:100-102.

Mahmoud MA, Al-Sohaibani SA, Al-Othman MR, El-Aziz ARM (2012) Biochemical screening of chocolate spot disease on faba bean caused by Botrytis fabae. Afr J Microbiol Res. 6(32): 6122-6129.
Neler J, Wassermann W, Kutner MH (1985) Applied linear statistical models. Regression, analysis of variance and experimental design: 2nd Ed. Richard, D. Irwin Inc. Homewood Illionois.

Otazu V, Brown WM, Quiton Mde (1982) "Enferme- dades de las plantas en Bolivia," Ministerio de Asuntos Campesinos y Agropecuarios/Instituto Boliviano de Tecnología Agropecuaria/Consorcio Internacional para el Desarrollo, Cochabamba.

Perello A, Monaco C, Simon MR, Sisterna M, Dal Bello G (2003) "Biocontrol efficacy of Trichoderma isolates for tan spot of wheat in Argentina," Crop Prot. 22 (9): 1099-1106.

Sharma P, Jha AB, Dubey RS, Pessarakli M (2012) Reactive Oxygen Species, Oxidative Damage, and Antioxidative Defense Mechanism in Plants under Stressful Conditions. J Bot. $26 \mathrm{p}$.

Shtienberg D (2000) "Modelling: the basis for rational disease management," Crop Prot. 19 (8-10): 747-752.

Smirnoff N, Dowdle J, Ishikawa T (2007) The role of VTC2 in vitamin C biosynthesis in Arabidopsis thaliana. Comp Biochem Physiol. A.146:S250.

Teshome E, Tagegn A (2013) Integrated management of chocolate spot (Botiytis fabae Sard.) of faba bean (Vicia faba L.) at highlands of Bale, south eastern Ethiopia. Res J Agric Environ Manag. 2(1): 11-14.

Torres SAM, Roman B, Avila CM, Satovic Z, Rubials D, Sillero JC, Cubero JL, Moreno MT (2004) Faba bean breeding for resistance against biotic stresses: Towards application of marker technology. Euphytica. 147: 67-80.

Williamson B, Tudzynski B, Tudzynski P, Van Kan JA (2007) "Botrytis Cinerea: The cause of grey mould disease," Mol Plant Pathol. 8 (5): 561-580.

Zinkernagel $V$, Tischner $H$, Hausladen $H$, Habermeyer $H$, Taborsky V, Polak J, Lebeda A, Kudela V (2002) Practical application of integrated disease management. Plant Prot Sci. 38: 212-222. 